\title{
THE PATENT LAWYER AND THE GENERAL PRACTITIONER
}

\section{RICHARD SPENCER $\dagger$}

Anyone undertaking a discussion of the relationship between the general lawyer and his highly specialized cousin the patent lawyer should proceed with a degree of trepidation. ${ }^{1}$ View, for instance, the caution and restraint just observed even in defining the degree of kinship between them. The term "brother" has not been overlooked, but it is felt that it might be objected to as being too affinitive: cousin, on the other hand, cannot be denied.

It comes about in this manner. Patent law is statutory, and our system, authorized by the Constitution, is about one hundred and fifty years old. This means that three or four generations back there were no patent lawyers; we were all of the same breed in spite of the difficulty that now lies in conceiving an evolution so rapid yet thorough. Counting back to the common ancestor and down again we find a degree of relationship that, while admittedly somewhat remote, is one the law must and does recognize.

In pondering this consanguinity, do not think that the patent lawyer is a country cousin. If anything, he is the one who left the ancestral abode and went to the city, there to acquire arts and urbanities beyond the comprehension of those from whom he departed. Today he indulges in mysterious performances that fall without the metes and bounds of the general practitioner's knowledge, and, it is feared that we must admit, also without his interest. Yes, failing in understanding, the general lawyer has become quite a bit disdainful of his specialized kin and regards him with a mixed attitude that is composed mainly of regret and despair mingled with tolerance. That this is unfortunate and perhaps unbecoming, must be admitted by both. Whether it is worth worrying about is something else.

If the patent lawyer is to become extinct like the dodo, his plight can, in accordance with the custom in such cases, be passionately disregarded. If, of the legal pie, he is only nibbling at a small portion of the crust, he can, also according to precedent, be ignored until his appetite drives him further, at which time stern measures can be applied. If either of these considerations holds, our discussion ends. Let us, then, investigate.

Patents are authorized by Article I, Section 8 of the Constitution, which provides :

† A. B., I924, George Washington University; LL. B., I927, Harvard University; Lecturer in Law at Northwestern University since ro3I; author of UNITED STATES PATENT LAw System (I93I), and articles in various legal periodicals.

${ }^{I}$ This discussion is intended neither as an indictment of one nor a vindication of the other, and certainly not as a challenge. The writer, as it happens, both practices and teaches patent law. 
". . . the Congress shall have power . . . to promote the progress of science and the useful arts, by securing to authors and inventors the exclusive rights to their respective writings and discoveries."

Therein lies the power of the legislature to adopt a system of patent laws, and experience dictates that where Congress can, Congress does; that while that body has the strength to turn out statutes, patents and patent lawyers will continue to exist. As proof, this ought not to be inconclusive, but, in case it should be, a quick glance at the history of invention will be assertive and convincing.

So recently that the memory of man runneth not to the contrary, barbarous nations were not only illiterate, but regarded learning with contempt. Even after they settled in the cultured countries which they had conquered, they would not suffer their children to be instructed in any science, for, said they, instruction in the sciences tends to enervate and depress the mind; and he who has followed the pursuits of comfort or learning will never look on a sword or spear with an undaunted eye. Even their chiefs lived in pompous indigence, destitute of even the meanest comforts and conveniences. Contrast such an outlook with contemporary ideas and then dare say that the attitude toward invention is not becoming increasingly favorable.

Next, compare one or two countries where invention flourishes with some where it does not, and be convinced that invention means progress: contrast China, for instance, where the inconveniences of obsolete processes are sanctioned by time, with the United States; and India, where the arts have made but little progress since the days of Alexander, in consequence of a superstitious dread of novelty, with Germany. Invariably it will be found that industrial development has been accompanied by the rewarding of inventors, and that the extent of progress made in a country has been in direct proportion to the generosity of the patent system toward inventors.

The United States is perhaps more liberal in rewarding its inventors than any other nation, and with what result? We are the most advanced industrially. Five of the world's leading industries have been developed in this country within the life of the reader: the automobile; the airplane; the radio; the telephone; and the motion picture. We stand on the brink of others as important, such for instance, as television and artificial atmosphere.

Judging the importance of patents from a somewhat different aspect, government has of recent years started, and will continue, to enter more and more into business. Preferably this is through supervision rather than competition. It is not unlikely that in time federal patent grants will serve as a further medium through which our governing agencies will reach business.

Every direction sign points therefore toward the increased importance of the patent system and it may be concluded that the chances of the patent lawyer dying out are, to understate the proposition, nil. 
On to our second line of inquiry. To what extent are these specialists indulging in the legal pie? Are they making money? How many of them are there? Who are their clients?

About ten thousand persons are registered to practice before the Patent Office and probably not many more than half of these can be said to be active. The other half includes some who have retired; others who enrolled for a single case; many who, although registered, are not deriving their income from patent law; employees of the Patent Office; and numerous foreign attorneys who are registered largely as a matter of form.

It is difficult to estimate the income of the patent bar, but we can go far enough to show that it is amazingly large, probably out of all proportion to the general field. Over a thousand patents are granted weekly or over fifty thousand annually. It is estimated that the average attorney's fee for each application is $\$ 200$, which makes a staggering total of well over ten millions of dollars that is received each year for the prosecution of allowable applications only. ${ }^{2}$ On top of that we must figure the vast amount of fees annually expended on applications that are filed in the Patent Office but never allowed. Furthermore, application work, although it might be regarded as the backbone of the practice, is generally considered the least remunerative end. Hundreds of patent cases, mainly infringement suits, are tried annually, and, owing to the complexities and the duration of this litigation, the fees are regarded by clients as being enormous and are even recognized by the attorneys as being fairly sizeable.

From what further sources does the patent lawyer enjoy an income? Perhaps the most lucrative of all is the rendition of opinions dealing with such questions as infringement, validity, novelty and the like. Then, in addition, he must represent his clients in regard to foreign patents; he must often serve as a negotiator in buying or selling patents; and he is called upon to settle controversies. Is this all? Not by a long sight. In addition to patent work it is customary to handle trade-marks, copyrights, and unfair trade and competition cases. Ordinarily the general lawyer pursues a handsoff policy with respect to all of these branches, leaving the revenues they offer to be divided among the patent bar. Is it any wonder that a patent law office will pay a law school graduate, having a rudimentary knowledge of patent law, two or three times the amount a general law office can afford to pay a graduate?

Our line of inquiry also went to the clients. Who are they? At the risk of wasting space the names of three dozen companies involved in litigation that has been reported in the Federal Reporter Series during the past year, are given herewith:

¿This figure may be considered too generous by some, but in the opinion of the author it is unduly conservative. It encompasses, of course, fees expended in prosecuting appeals and interferences. 


\author{
United Drug Co. \\ Goodyear Co. \\ Hartford Empire Co. \\ Westinghouse Electric Co. \\ Western Electric Co. \\ Loose-Leaf Co. \\ Great Northern Ry. \\ Cleveland Trust Co. \\ American Can Co. \\ Bassick Co. \\ National Tool Co. \\ Radio Corporation of America \\ Otis Elevator Co. \\ Harley Davidson Co. \\ Bohn Refrigerator Co. \\ General Electric Co. \\ N. Y. Rapid Transit Co. \\ International Silver Co.
}

General Motors Corp.

Eastman Kodak Co.

Conde Nast Publications.

Vacuum Oil.

Goodrich Co.

Guaranty Trust Co.

Union Switch \& Signal Co.

Moto-Meters Co.

Warner Bros.

Ford Motor Co.

Timken Detroit Co.

Stewart-Warner Co.

Stutz Motor Co.

Kraft-Phenix Cheese Co.

Neon Lights

Standard Scale Co.

Eskimo Pie Corp.

F. W. Woolworth Co.

Suffice it to say that every large company is coming to rely more and more on patent protection and consequently, under normal conditions, appropriates each year an increased sum for that purpose. Manufacturers find they can gain competitive advantages only through reduced manufacturing costs or the offering of novel or improved products and that the only way to hold these benefits is through patent protection.

We have seen enough to justify us in proceeding further with our discussion. Patents are here to stay for at least an indefinite period, and the patent lawyer is, to state it in the most conservative way possible, getting his share of the pie. In ordinary times and under normal conditions he will be one of the last to enter the legal bread line.

While some reader might resent the indictment that the two bars are segregated and that the general lawyer looks askance upon his eccentric colleague, our critic in this regard would in all probability be a patent lawyer. The general practitioner usually admits with alacrity, and often seems to gain considerable happiness from his confession, that he knows nothing whatsoever about patents, and that if a client casually mentions the word he is immediately thrown into a state of confusion. The patent lawyer, on the other hand, modestly confesses that although he confines his energies to a narrow field he fortunately entertains a thorough comprehension of law in all its forms. Indeed, there are some of the latter who, with charming candor, acknowledge this dual proficiency by practicing both sciences. Despite the efforts of this last expert to bridge the gap, by standing with one foot on patent law soil and the other on general law, his very presence but serves to accentuate the chasm beneath. As far as that goes, the lawyer who 
confines his attention strictly to patent matters is regarded as somewhat of a curiosity, as evidenced by the following reflection cast by our Chief Justice:

"You are the priests of the inner-mysteries of the temple of justice. Even in your gladsome moments you have the air of being on familiar terms with the doctrine of relativity, and that puts companionship to a severe test." 3

To prevent possible misconception at this point, it should be mentioned that the gulf is restricted to the professional side and, happily, does not carry over into the social end of things. Once the patent lawyer leaves his office, the very air of which may be muggy with the heavy technicalities of patents, he is likely to shed all peculiarities of outlook and language and become normal in both action and appearance. Running for the suburban train, nothing unusual marks him. Among strangers he fails to draw an inquisitive glance or even a patronizing smile. On the golf course he counts, or fails to count, about the same number of strokes as other members. $\mathrm{He}$ is, in short, much the same as the next person and becomes a thing unto himself only when he pauses to dwell on his particular subject.

In contemplating the existence and necessity of a class, it is customary to delve into the past and examine its history and background. A detailed and extensive survey of the development of the patent system is beyond the province of this article and is apt to fall even farther beyond the interest of the reader, if he chances to be a general lawyer, but a very brief résumé dealing with its origin and early history will be risked.

When our Constitution was drafted, there were, unquestionably, only a very few individuals concerned with it who knew anything about patent law. A few of the States had granted patents for inventions, it is true, but ours was almost entirely an agrarian and trading community in those early days and hence the subject of invention played little part in colonial life and the topic accordingly received scant consideration.

In the early drafts of the document, even down through the one submitted the Convention on August 6, I787, there had been no mention of patents, but a few days later, on Saturday, August I8, Mr. Thomas Pinckney announced to the Convention that several additional prerogatives had occurred to him and these included the powers :

"6. To secure to literary authors their copyrights for a limited time.

"7. To secure to inventors of useful machines and implements, the benefits thereof for a limited time."

On Wednesday, September 5, Mr. Brearley, representing the Committee of Eleven, proposed the adoption of these measures, although combined into

${ }^{3}$ Address by Mr. Chief Justice Hughes to American Patent Law Association, February I4, 1929. 
a single section as it now stands, ${ }^{4}$ and the Convention agreed to the proposal without argument.

Six years later the first patent act was passed and the responsibility of conferring the grants was vested jointly in the Secretary of State, the Secretary of War, the Attorney General and the President of the United States. If these officers held the same assignment today they would have no time to devote to such matters as wars, insurrections, taxes, foreign affairs and the decimal point in beer, but immediately afterward we catch our first glimpse of the practice that was later to become so popular in the administration of the patent system, namely, shifting the responsibility. The Department of State was soon given the load and carried it until the Department of the Interior was created whereupon that department took it over. Later on it was transferred from the Department of the Interior to the Department of Commerce where it now rests. Out of it, by the way, has grown the Department of Agriculture. It is only fair to mention that notwithstanding this constant buffeting about, the Patent Office is practically the only department in the Government that has made money. In spite of adversity and all else it has brought millions of dollars of cash revenue into our national treasury.

At the outset, the task of securing a patent grant was much the same as securing a land grant, with this notable exception: land, being fixed and immovable, could be clearly and accurately described by reference to its boundaries as marked by physical objects, whereas the boundaries of an invention being metaphysical and unknown, could only be fixed by indirection and conjecture. In describing land it was necessary to describe only the boundaries, whereas an invention, which generally related to something chemical, mechanical or electrical by nature, had to be described itself. The two would have been analogous if the scope of an invention could have been defined by reference to longitude and latitude, or, alternatively, if a piece of land had to be described by such accurate reference to the contour of its surface, the texture of its soil, and the appearance of its landscape as would enable it to be distinguished from all other land. Indeed a task that would cause his life history to go fleeting before the eyes of the most expert conveyancer.

The necessity of making a full and exact description of the invention was obvious. It served two purposes. To begin with, patents were, and still are for that matter, in the nature of contracts, whereby in consideration for the grant, the inventor made a full and public disclosure of his invention. In this way, when the grant expired the public could learn, by referring to the disclosure, how to practice it thereafter. Secondly, the terms of the grant had to be definite so that the public could guard against infringing it, and to this latter end the description defined the extent or scope of the monopoly.

“United States Constitution, Art. I, Sec. 8. 
When the disclosure was required the bar went into labor and brought forth the patent lawyer. His evolution was slow, for when patents first were granted the general lawyer could, with the aid of the inventor, undoubtedly draft a sufficient disclosure to enable a person skilled in the art to comprehend the invention. However, in due time though the system expanded; thousands, hundreds of thousands, of patents were granted; inventions became more complex, more replete with technicalities, and the task of the general practitioner was soon herculean, and, shortly afterward, hopeless. It became obvious that in order properly to prepare patent applications, a knowledge of the sciences was highly desirable, if not essential. With the realization of that fact, the element of engineering projected itself into the picture. Instead of dividing the responsibility, between the engineer and the general lawyer, the patent lawyer made his debut; he who was proficient in both engineering and law.

Historically there is another factor that has contributed to the distinction being discussed. Not long after the Patent Office had been created, a group of persons appeared, opened quarters in the neighborhood, and made the office their daily headquarters. These men termed themselves patent agents or attorneys and when inventors came to the Office seeking information the former accosted them and offered their services. As a rule, they were not lawyers or members of the bar. Furthermore, since they had no professional ethics to observe their conduct was not always exemplary. Many of them were incompetent and they soon came to acquire an unenviable reputation that in some respects has continued to cling to the patent bar down to the present.

Even today a man may register before the Patent Office, though he be not a member of the bar, and this has caused unfortunate shadows to fall upon the patent profession. The general practitioner knows that many of those practicing before the Patent Office are not lawyers and not being patient enough to draw the distinction between them and those who are lawyers, he places both in the same category. Similarly, the rules and regulations governing admission and practice before the Patent Office are lenient, perhaps far too much so, and in the existing rules there is nothing to prevent an attorney from advertising. The result is that many indulge in this offensive practice and the fraternity being small, the actions of these few are reflected upon the entire group. Thus, when the general practitioner pauses to consider the patent lawyer these thoughts enter his mind: "They advertise. They don't have to be lawyers."

We have finished with the evolution of the patent lawyer, and we see that he belongs to one of three classes: (I) A composite lawyer and engineer; (2) an engineer who has studied law, or (3) a lawyer who has studied engineering. Let us try to detect which class contains the greatest number, and 
then, if we discover that our subject is primarily an engineer or primarily a lawyer, let us investigate the degree of success he is meeting with in the other half of his dual role. In doing this we will do well to refer first to his training, and then to his professional accomplishments.

With one or two exceptions no law school outside of Washington, D. C., endeavors to afford instruction in Patent Law. ${ }^{5}$ In making this single observation we set forth the leading current cause underlying the high degree of specialization in the patent law field. In other words, it comes to this : In practically no school in the country can the student study patent law. If, for some reason, he wishes to receive training in this field he is, as a practical matter, compelled to forego his wish or to enter one of the universities in the nation's capital. Mind you, it is not suggested they are not satisfactory schools, for they are, and they offer excellent training in patent law, but over 90 per cent. of those studying law attend other schools that do not offer opportunities for training in this restricted field.

Inquiries sent to a number of our leading schools met with responses that were practically uniform in giving as a reason for this lack of instruction the fact that there is practically no demand for it. Rarely is there a demand for something not on the bill of fare. However, isn't the law school shirking its responsibility when it awaits the demand of students before adding a course to the curriculum? Heavens knows, if the general practitioner shies from patent law we can hardly expect to find a student clamoring for it. Surely the responsibility should belong to the school. If the field is lucrative and offers a splendid opportunity to the right men and if the general bar is overcrowded and overrun, as it is, shouldn't the teaching of the very fact that these conditions exist comprise a most important duty? At least students should be taught the facts and circumstances surrounding the practice of patent law. When once this is done there may be a demand. A major undertaking of law schools should be the distribution of its graduates to the fields of law that need them. If the general bar is surfeited, the specialized fields should be considered. As stated, the schools now teaching patent law are competent but running patent lawyers through the same mold tends towards standardization, lack of contrasting viewpoints, and the absence of independent observation, all of which are definite handicaps in the legal profession.

Before passing from this phase of the subject, let us pause to consider the present day educational curriculum of the great majority of patent lawyers: First comes the decision to be an engineer, followed by a course in that subject at some duly accredited university. Upon graduation, our man is chagrined to discover that as a builder of bridges and vast monuments, there is no particular call for his services. About this time he learns that the

'Members of the Association of American Law Schools outside of Washington, D. C., offering courses: Northwestern University, Michigan University, Boston University and Western Reserve University. 
federal civil service department is giving an examination for Patent Office examiners and that the pay of an examiner is more than he can earn elsewhere. Being duly qualified from the educational standpoint, he passes the rigorous entrance examination and becomes an examiner. Until this point is reached, our subject has always been strictly an engineer. From now on, however, he finds that he is called upon to perform, with his fellow examiners, the quasi-judicial functions of the Patent Office, and likewise learns that most of his fellows are attending evening law classes. Soon he is encouraged to do likewise. He is informed that with Patent Office training and a legal education, he can step into a job that, in all likelihood, will pay him considerably more than his engineering classmates will be making by that time. $\mathrm{He}$ finds slight objection to carrying the added burden of going to school because most of his associates are doing the same thing and the classes themselves are arranged with a view to accommodating students who have worked all day in the government departments. $\mathrm{He}$ is offered ample courses in the various phases of patent law and when he graduates he stands upon the professional threshold as an engineer who, in the majority of cases, has taken on law mainly as a sideline, although it will later become the staff of his professional life.

Thus, it may be seen that while in practice the order becomes reversed, the patent lawyer is, by education, primarily an engineer, and, secondarily, a lawyer. This being so, let us pause for a moment to view the progress he is making in the legal field.

Patents for inventions did not exist at common law, and, accordingly, they depend for their existence upon statutory enactments. All United States statutes defining the substantive law of patents could be set forth on a few pages of this publication.

In spite of the brevity of the substantive law there has developed under it a body of case law that is literally shot with confusion, doubt and conjecture. No detail or technicality of the law is too infinitesimal for the engineering side of the patent lawyer to explore, take apart, investigate, and complicate. Where the patent lawyer has dealt with a simple code of substantive law he has brought about results that are chaotic and conflicting beyond understanding. Rarely does a question of substantive law arise that can be settled by reference to a uniform line of cases and the result is that strife and litigation control most of the disputes that arise. On this point also we can find language of our Chief Justice which, although employed humorously in addressing the patent bar, sets forth many a truth:

"I cannot look upon these ultra-intelligent faces without the deepest sympathy for the judges, who can never be sure that they are right. They must be tortured with uncertainties which even survive their decisions. The first is the district judge, who has the maximum oportunity for going wrong. He must at least appear to have mastered the art, 
and after this hard-won victory, he must apply the law. In going through the decisions he may have the experience of the justice of the peace who, wrestling with a great question, traced the law satisfactorily to a given point and then exclaimed, 'And here, God help me, the law forks.' Then there is the Circuit Court of Appeals, which when it escapes the snares of counsel is always in danger of being misled by the trial judge. The defeated litigant is apt to think that the appellate court, in dealing with these abstruse questions of invention and infringement is the court of ultimate conjecture and final error. But the Supreme Court is occasionally a last resort. That court is well protected from your assaults. Ordinarily it will not expose itself to the dangers of intrusion into your realms without being fortified with the conflict of decisions between at least two Circuit Courts of Appeals. It thus has the unusual advantage, not only of the conflicting arguments of counsel, but of the conflicting opinions of courts, so that whatever its decision it will have strong support. I was asked the other day to tell you what the Supreme Court thinks of patent cases. I am sure that I do not know, and if I did know, I would not tell you. I should be glad to know what you think of court decisions if you could tell it in language which a plain man could understand and properly repeat." ${ }^{6}$

We have another opportunity to contemplate the patent lawyer's love of detail and intricacy. Congress is composed mainly of lawyers and, as stated, it has developed a body of substantive law which, although adequate, is reasonably brief. In one section of the Congressional act ${ }^{7}$ the Commissioner of Patents is authorized to established regulations for the conduct of proceedings in the Patent Office. Acting on this authority, the patent bar has developed a set of rules which in bulk exceed the entire system of substantive law! Here, the engineer with a leaning toward technicalities and minutia, has done himself proud. He has established rules of practice and procedure that even the most astute patent lawyer finds it difficult, if not impossible, to follow. Interferences, for instance, they being those proceedings that are instituted to determine the question of priority of invention between two or more applicants claiming the same patentable subject matter, are governed by a set of rules, which for complexity seem not to have been approached since archaic laws of special pleading were abandoned.

We can see, therefore, that the patent lawyer finds it difficult to divorce his engineering training from his legal work and he thereby contributes to the difficulty under discussion by building up a body of law that is so replete with technicalities that it requires a mind schooled in engineering and the sciences to comprehend it. It was the late Chief Justice Taft who said, in words approaching these, that it is easier to make an engineer out of a lawyer than it is to make a lawyer out of an engineer.

- Hughes, supra note 3.

${ }^{7} 32$ STAT. 830 (I903), 35 U. S. C. A. §6 (1929). 
From time to time movements have been made to improve and simplify Patent Office practice and procedure as well as to iron out some of the intricacies that prevail on the substantive law side. These attempts can be classed chronologically under three headings: first, legislative; second, executive; and third, those made by bar associations.

The first of these commenced several years ago, when Congress undertook to investigate the patent system and thereafter made a number of recommendations looking toward improvement. All of these were decisively defeated by the patent bar. Next, executives, for example, the Secretary of Commerce, appointed committees of prominent lawyers to review the patent system and recommend changes. Here again numerous improvements relating to practice were advised but practically all of them were immediately defeated by the patent bar. More recently the Patent Section of the American Bar Association has devoted endless hours to a consideration of the patent system and the formulation of measures calculated to improve it. Yet, almost without exception, these have been rejected as quickly as they have been placed before the patent bar. Unquestionably these three efforts of the past establish the following two truths: (I) Every one who has paused to investigate carefully and thoroughly the existing system has found it deficient and needful of improvement; (2) Wherever substantial improvement has been proposed the patent bar has immediately opposed and defeated it. We see, therefore, that the patent lawyer has not only developed an intricate system of law and procedure but he furthermore insists upon keeping it. In spite of castigation by the courts, ${ }^{8}$ the patent lawyer seems well satisfied with the fabric of his laws, the texture of which is so forbidding that general lawyers throw up their hands when confronted with it. Reactionary or conservative in the extreme, an engineering training has schooled the patent lawyer in technicalities and details, has rendered him immune to the difficulties of meticulous research and the cross currents of investigation.

At this point, let us pause for a moment and again summarize our findings. In the first place, present indications are that patents are here to stay for an indefinite period and they are apparently growing in importance. Next, there is a decided gulf between the patent bar and the general bar. Lastly, the gulf has probably been brought about by the emphatic part engineering is playing in the practice of patent law. Certainly it will be agreed that such a division of the bar is undesirable; likewise that a legal system engendered with engineering to the extent described is ill-advised. Having made these findings, let us, in conclusion, consider ways to eliminate the objectionable conditions that now exist.

${ }^{8}$ See, for instance, Judge Mayer's decision in Kinter et al. v. Atlantic Communication Co. et al., 5 I F. (2d) Iog (S. D. N. Y. I93I); and also Judge Tuttle's decision in Fruehauf Trailer Co. v. Highway Trailer Co., 54 F. (2d) $69 \mathrm{I}$ (E. D. Mich. r93I). 
Various possibilities are brought to mind and of these, some of the more remote and less important will be considered first. To begin with, if the patent system continues to expand, become more complex and reform is denied it, it is only fair to predict that eventually it will collapse of its own weight. When this occurs it can be prophesied that the law of unfair trade and competition will take over the functions that the patent system is performing at present. Today this new body of law is constantly encroaching upon the field of pure patent law and it likewise is daily growing in importance. It is not impossible to imagine a system of business courts located over our country having equity and law jurisdiction and administering the doctrines of unfair trade and competition, including additionally the performance of those functions at present being carried on by the patent, copyrights, and trade-mark systems, the federal trade commission, and many other kindred instrumentalities. Since there is nothing unusual or mysterious about the law of unfair trade and competition, and inasmuch as it falls as squarely within the general law field as it does within patent law, it is fair to assume that if ever our patent system should give way and be replaced by this more comprehensive body of law, the distinction between the two bars would rapidly disappear.

Another practice that would have a tendency to break down the distinction and one that is being indulged in today to an increasing extent, is that of employing patent lawyers in large general offices and turning over to them cases arising in their specialized field. This will slowly have the effect, by reason of association if nothing else, of wearing away the distinction between the two branches. Other contingencies come to mind, but rather than enter fields too remote, let us proceed to the most important.

We have seen that the patent lawyer is, from an educational standpoint, primarily an engineer, and secondarily, a lawyer. Owing to this he has allowed, perhaps involuntarily, his "engineering mind" to govern him largely in his practice of law. This type of mind is far removed from that known as "a legal mind". The two stand somewhat at opposite poles. In order to reverse the condition of things, it seems obvious that the best procedure is to shift the emphasis from engineering to law. In other words, instead of the patent attorney being primarily an engineer, make him primarily a lawyer, and if necessary, secondarily, an engineer. The most feasible way in which this can be done is by having our better class law schools, or some of them, afford instruction in patent law. Not such brief instruction as is now being offered in the few schools, other than those in Washington, D. C., that teach the subject, but a number of adequate courses that will enable the graduate to embark forthwith upon the practice of patent law. If a certain amount of engineering training is desirable, that can be arranged, but in time it will not be essential. If a man has such a turn of mind toward mechanical 
things as would lead him into the practice of patent law, he can probably assimilate as he goes along, a sufficient knowledge of the subject that he is investigating to permit him to proceed with confidence and intelligence. Observe, for instance, the fact that all of our patent decisions are rendered by general lawyers and yet they seem to be capable of acquiring sufficient knowledge of the subject matter before them to enable them to render an opinion that is learned and judicious.

Therefore, the real solution to the problem is believed to be the inclusion in law school curriculums of the subject of patent law and kindred subjects. Where there exists a field of law of general interest (as contrasted, for instance, with admiralty which is confined to seacoasts) that is constantly growing and developing, law schools, or at least some of them, should endeavor to train men for work in that field. By so doing, the undesirable features that have been discussed will be avoided. Specialization is not undesirable unless it interferes with a man's primary occupation, which is what an engineering training does with the practice of law, or unless it does not enable him to see past the technicalities involved and weigh such constantly changing elements as economic and social development. Patent lawyers, for example, have repeatedly expressed themselves as being unwilling to have a court, the jurisdiction of which would be confined to appeals in patent cases. Such a court, say the lawyers, would enter a rut and would not give good decisions. By the very act of criticising the creation of such a court, the patent bar places its stamp of disapproval upon its own line of specialization.

The engineering aspect of patent law cannot be ignored, but if men who are primarily coached in law started entering the patent field in numbers, it would not be long until the engineering aspect would be relegated to a place of comparative unimportance. Just as the lawyer employs an expert in a case involving medicine, accounting, or the like, he will soon have his profession so adjusted that he can employ, with equally good results, an expert in a case involving engineering.

In closing, let this be a plea to eliminate the distinction between the patent bar and the general bar, by having law schools examine the comparative opportunities and needs of the two fields and thereafter take steps to train men for both. The problem of the law school, in this regard, admittedly will be a formidable one, but that in no wise lessens the necessity for undertaking it. As things are now going, the patent bar will continue to develop and increase out of proportion to the general bar and as long as that takes place, the problem will constantly become larger and more difficult. It is unfair to industry and it is unfair to the bar, for law schools to refuse to recognize the responsibility as theirs and cope with the question. Furthermore, all indications point toward the fact that the first schools to solve the problem will in time be adequately repaid for their efforts. 